\section{Pleiotropic Effects in Transgenic Tobacco Plants Expressing the Oryzacystatin I Gene}

\author{
Rafael Gutiérrez-Campos ${ }^{1}$, Juan Antonio Torres-Acosta, and \\ José de Jesús Pérez-Martínez \\ Departamento de Química, Universidad Autónoma de Aguascalientes, Av. \\ Universidad No. 940, Col. Bosques CP 20100 Aguascalientes, Ags., México \\ Miguel Angel Gómez-Lim² \\ Departamento de Ingeniería Genética de plantas, Centro de Investigación y de \\ Estudios Avanzados del I.P.N.(CINVESTAV) UnidadIrapuato, AP 629, Irapuato, \\ Gto. 36500, México
}

Additional index words. Nicotiana tabacum, cystatins, phenotype, pleiotropy, cysteine proteinases

\begin{abstract}
A study was undertaken to evaluate possible phenotypic alterations in transgenic tobacco (Nicotiana tabacum L. cv. Xanthi) plants expressing the oryzacystatin I gene. Morphophysiologic parameters, such as growth rate, biomass, and leaf, flower, and fruit characteristics were analyzed. Transgenic plants overexpressing the cysteine proteinase inhibitor showed increased growth rate and dry weight, earlier flowering, and increased numbers of flowers and seeds. These pleiotropic effects were correlated with expression level of oryzacystatin I in transgenic lines. The results suggest that oryzacystatin I disrupts the normal activity of cysteine proteinases, which are involved in important physiological processes.
\end{abstract}

Cystatins are strong, natural inhibitors of cysteine proteinase activity. They have been identified in a wide variety of organisms ranging from bacteria to human cells (Turk and Bode, 1991). They occur in seeds (Fernandes et al., 1993), tubers (Waldron et al., 1993), and ripening fruit (Dopico et al., 1993). In contrast to the substantial progress achieved in characterizing the structure of plant cystatins, the physiological function of these proteins is not well understood. Nevertheless, at least two functions have been proposed: regulation of protein turnover and host plant defense against insects (Botella et al., 1996). Because a number of insects and nematode species contain cysteine proteinases in their intestines, where food is digested, overexpression of cystatins in transgenic plants may be an efficient way to control those plant pests (Ryan et al., 1990).

One of the best characterized plant cystatins, identified from rice (Oriza sativa L.) seeds, is oryzacystatin I (Abe et al., 1987), which has been overexpressed in transgenic plants and has insecticidal activity (Orr et al., 1994). The cysteine proteinases of higher plants may fulfill an important role in cell metabolism, and their inhibition by cystatin overexpression in

Received for publication 8 Dec. 1999. Accepted for publication 24 May 2000. Use of company or product names does not imply approval or recommendation of the product to the exclusion of others that also may be suitable. The cost of publishing this paper was defrayed in part by the payment of page charges. Under postal regulations, this paper therefore must be hereby marked advertisement solely to indicate this fact.

${ }^{1}$ E-mail address: rgutierr@dq.uaa.mx

${ }^{2}$ To whom requests for reprints should be addressed.

E-mail address: mgomez@ira.cinvestav.mx transgenic plants might cause undesirable phenotypic alterations. To address this issue, a study was undertaken to examine the phenotypic characteristics of transgenic tobacco plants overexpressing the oryzacystatin I gene.

\section{Materials and Methods}

Plant material. Transgenic Nicotiana tabacum plants (cv. Xanthi) used in this study were obtained as described previously (Gutiérrez-Campos et al., 1999) and contained the oryzacystatin I cDNA under the control of the $35 \mathrm{~S} \mathrm{CaMV}$ promoter. The transgenic plants were maintained in a greenhouse at $25^{\circ} \mathrm{C}$ with daily irrigation and were fertilized with onehalf strength Murashige-Skoog (MS) salts every 3 weeks.

Analysis of the expression level of the inhibitor in transgenic lines. The quantification of inhibitor in leaves of parental lines was performed by a papain inhibition assay according to Masoud et al. (1993). Initially, crude extracts from leaves were prepared in phosphate buffer $(0.13 \mathrm{M} \mathrm{NaCl}, 0.002 \mathrm{M} \mathrm{KCl}$, $0.01 \mathrm{M} \mathrm{Na}_{2} \mathrm{HPO}_{4}, 0.001 \mathrm{M} \mathrm{KH} \mathrm{PO}_{4}, \mathrm{pH} 7.0$ ) and centrifuged at $10,000 \times g_{\mathrm{n}}$. Protein concentration was determined in the supernatant by the Bradford (1976) method. Papain (1.5 $\mu \mathrm{g}$ ) was added to $75 \mu \mathrm{g}$ of total soluble protein plus L-cysteine as activator and the mixture was preincubated at $37^{\circ} \mathrm{C}$ for $15 \mathrm{~min}$. Subsequently, $2 \mathrm{mg}$ of $\mathrm{n}$-benzoyl 1 -arginine $\rho$ nitroanilide (BAPNA) (Sigma Chemical Co., St. Louis) were added and the mixture was incubated for a further $60 \mathrm{~min}$ at $37^{\circ} \mathrm{C}$. Enzyme activity was determined by absorbance at $410 \mathrm{~nm}$. Values obtained were expressed as a percentage of the activity of control extracts (no inhibitor present). The transgenic lines obtained were selfed and kept at $25^{\circ} \mathrm{C}$ for seed production.

Selection of homozygous plants. Seeds from the $\mathrm{R} 1$ progeny from plants showing the highest (H3) and the lowest (E5) accumulation of inhibitor, and in which previous studies had indicated that the transgene had segregated in a 3:1 ratio, were germinated in MS medium containing $120 \mu \mathrm{g} \cdot \mathrm{L}^{-1}$ kanamycin (Sigma). Plants showing increased vigor, growth, and papain inhibition were considered homozygous; those plants not showing incorporation of the transgene (as indicated by PCR) were considered as control plants.

Phenotypic analysis of transgenic plants. The following phenotypic characters were examined in 18 individuals of the R1 progeny of the two selected transgenic lines: height, growth rate, biomass, number of leaves and axillary buds, time of flowering, and number and morphology of flowers and fruit. Data were tested by analysis of variance. When significant differences were found, the values were compared according to the Tukey-Kramer multiple comparison test $(P \leq 0.01)$.

\section{Results and Discussion}

Analysis of papain inhibition in crude extracts from RO transgenic plants. Based on inhibition assays, two lines showing the highest and the lowest accumulation of the inhibitor were selected from all the R0 transgenic lines. Crude extracts from line $\mathrm{H} 3$ inhibited papain activity $43 \%$, whereas crude extracts from line E5 inhibited it only 5\% (Table 1).

Phenotypic analysis of transgenic plants. Growth. A direct relation was evident between the expression level of the inhibitor and growth rate (Fig. 1). In all determinations, all plants from line $\mathrm{H} 3$ were taller than control plants, whereas plants from line E5 were comparable to control plants in height (Fig. 2). These results are supported by biomass determinations, where the dry weight of plants from line $\mathrm{H} 3$ was $34 \%$ greater than that of the controls (Table 2). Interestingly, the growth rate of plants from line $\mathrm{H} 3$ fell from $154 \%$ to $111 \%$ of the control plants between 85 and $90 \mathrm{~d}$ after germination (Fig. 1). By this time, plants showed signs of advanced senescence. These results suggest that constitutive expression of the oryzacystatin I not only accelerates the growth rate but also shortens the life cycle.

Table 1. Inhibition of the activity of papain by crude extracts from transgenic plants expressing the oryzacystatin I gene.

\begin{tabular}{lc}
\hline & \multicolumn{2}{c}{ Papain activity $(\%)^{2}$} \\
\hline Control & 100.0 \\
E5 & Transgenic line \\
B4 & $94.6 \pm 4.2$ \\
C3 & $93.9 \pm 0.65$ \\
H3 & $62.4 \pm 0.08$ \\
\hline
\end{tabular}

${ }^{2}$ The data are presented as the reduction in papain activity relative to control (not transformed) plants $(=100 \%$ papain activity $)$ and represent the means of three replicates. 


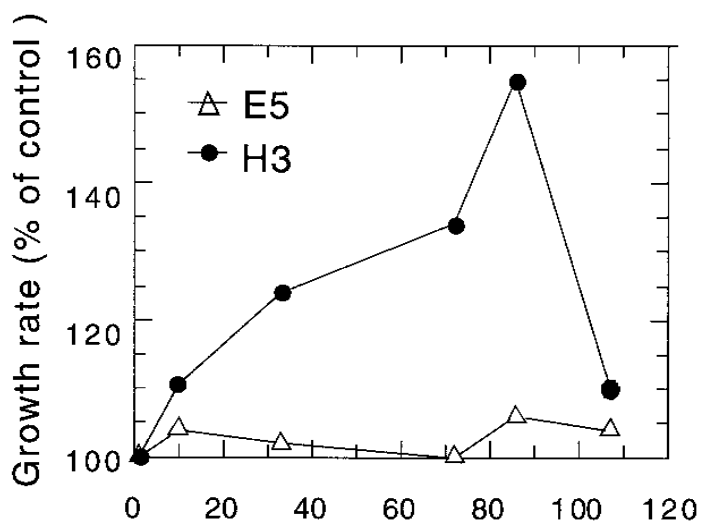

Days post-transplant

Fig. 1. Growth rate of transgenic plants expressing the oryzacystatin I gene. The values shown represent the growth rate of transgenic plants as a percentage of that of control plants. The values represent the mean of 18 individual plants.

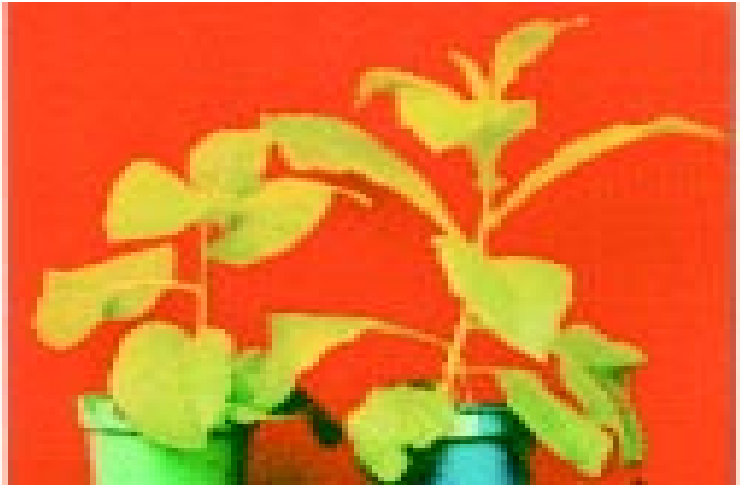

Fig. 2. A comparison of a control and a transgenic plant. Seeds from control and transgenic plants were germinated and seedlings maintained in a greenhouse at $25^{\circ} \mathrm{C}$. Plants were irrigated daily and were fertilized with one-half strength MS salts every 3 weeks. The plants shown are $50 \mathrm{~d}$ old. (left) Control plant; (right) transgenic plant (line $\mathrm{H} 3$ ).
Effect on leaves. No significant differences were found in the number of leaves or axillary buds in any transgenic line examined (data not shown). However, leaves from transgenic plants were larger and darker (Fig. 2).

Effect on flowering. An inverse relation was found between the expression level of the inhibitor and time of appearance of floral buds. Flowering occurred $\approx 25 \mathrm{~d}$ earlier in line $\mathrm{H} 3$ plants than in control plants (Table 2). These results support the earlier suggestion that constitutive expression of the inhibitor shortens the life cycle of transgenic tobacco plants.

Plants with a higher level of inhibitor (H3) produced more flowers than did control plants (Table 2). However, some aspects of flower morphology, such as size, and width, or weight of the pistil, were not affected (data not shown).

Effect on fruit. In agreement with the results on flowering, plants from line $\mathrm{H} 3$ produced more fruit per inflorescence than did control plants, although the differences were nonsignificant (18.8 vs. 16.0). Size and weight of the fruits was similar in transgenic and control plants (data not shown).

Effect on number of seeds and seed germination. Fruit in all transgenic plants contained more seeds than did fruit of control plants, including those with a low level of inhibitor. Even lines with low levels of the inhibitor, such as E5, produced more seeds than did the control (Table 2). However, germination percentage was not affected (Table 2).

These results demonstrate unexpected phenotypic effects induced by constitutive expression of the oryzacystatin I in transgenic tobacco lines. Because higher plants contain endogenous cysteine proteinases involved in different processes (Kato et al., 1999; Yonezawa et al., 1998), we originally had hypothesized that constitutive expression of the inhibitor might be detrimental. However, the changes observed in growth rate, biomass, flowering time and number, and morphology of flowers and seeds are beneficial traits for many agricultural crops. Cysteine proteinases have recently emerged as key enzymes in the regulation of programmed cell death of animals and plants (Solomon et al., 1999), and have an important role in plant senescence (Guerrero et al., 1998). It is tempting to speculate that constitutive expression of the inhibitor disrupts the normal activity of the cysteine proteinases involved in these last processes, resulting in an accelerated growth rate and altered programmed cell death.

We obtained very similar results to those presented here using a different tobacco cultivar Vena Amarilla (data not shown). Currently, we are evaluating the effect of constitutive expression of inhibitors from different sources in transgenic plants of tomato (Lycopersicon esculentum Mill.) and Physalis ixocarpa Brot. ex Hornem.

Constitutive expression of the oryzacystatin I gene induces pleitropic effects in transgenic tobacco plants. Clear alterations were induced in growth rate, biomass, flowering time, and number of flowers and seeds. If these effects can be demonstrated in other crops, the expression of cystatin genes may be utilized in a controlled manner to enhance desirable, specific, agronomic characters.

\section{Literature Cited}

Abe, K., Y. Emori, H. Kondo, K. Susuky, and S. Arai. 1987. Molecular cloning of a cysteine proteinase inhibitor of a rice (oryzacystatin). J. Biol. Chem. 262:16793-16797.

Barret, A.J. 1987. The cystatins: A new class of peptidase inhibithor. Trends Biochem. Sci. 12:193-196.

Botella, M.A., Y. Xu, T.N. Prabha, Y. Zhao, M.L. Narisham, K.A. Wilson, S.S. Nielsen, R.A. Bressan, and P.M. Hasegawa. 1996. Differential expression of soybean cystein proteinase inhibitor genes during development and in response to wounding and methyl jasmonate. Plant Physiol 112:1201-1210.

Bradford, M.M. 1976. A rapid and sensitive method for the quantification of microgram quantities of protein utilizing the principle of protein-dye binding. Anal. Biochem. 72:248-254.

Dopico, B., A.L. Lowe, I.D. Wilson, C. Merodio, and D. Grierson. 1993. Cloning and characterization of avocado fruit mRNAs and their expression during ripening and low-temperature storage. Plant Mol. Biol. 21:437-449.

Fernandes, K.S.V., P.A. Sabelli, D.H.P. Barratt, M. Richardson, J. Xavier-Filho, and P.R. Shewry. 1993. The resistance of cowpea seeds to bruchid bettles is not related to levels of cysteine protein-
Table 2. Effect of oryzacystatin I gene expression on phenotypic characters of tobacco plants.

\begin{tabular}{lrcr}
\hline & \multicolumn{3}{c}{ Genotype } \\
\cline { 2 - 4 } Characteristic & Control & E5 & H3 \\
\hline Dry wt. (g) & $58 \mathrm{a}^{\mathrm{z}}$ & $60 \mathrm{a}$ & $77 \mathrm{~b}$ \\
Time to flower (d) & $100 \mathrm{a}$ & $95 \mathrm{a}$ & $76 \mathrm{~b}$ \\
No. flowers/inflorescence & $15 \mathrm{a}$ & $14 \mathrm{a}$ & $20 \mathrm{~b}$ \\
No. seeds/fruit & $2378 \mathrm{c}$ & $2671 \mathrm{a}$ & $3076 \mathrm{~b}$
\end{tabular}

${ }^{\mathrm{z}}$ Mean separation within characteristics by TukeyKramer multiple comparison test, $\mathrm{P} \leq 0.01$. Each value is the mean for 18 observations.

ase inhibitors. Plant Mol. Biol. 23:215-219.

Guerrero, C., M. de la Calle, M.S. Reid, and V. Valpuesta. 1998. Analysis of the expression of two thiolproteinase genes from daylily (Hemerocallis spp.) during flower senescence. Plant Mol. Biol. 36:565-571.

Gutierrez-Campos R., J.A. Torres-Acosta, L.J. Saucedo-Arias, and M.A. Gomez-Lim. 1999. The use of cysteine proteinase inhibitors to engineer resistance against potyviruses in transgenic tobacco plants. Nature Biotechnol. 17:1223-1226.

Kato, H., A. Shintani, and T. Minamikawa. 1999. The structure and organization of two cysteine endopeptidase genes from rice. Plant Cell Physiol. 40:462-467.

Masoud, S.A., L.B. Johnson, F.F. White, and G.R. Reeck. 1993. Expression of a cysteine proteinase inhibitor (oryzacystatin-1) in transgenic tobacco plants. Plant Mol. Biol. 21:655-663.

Orr, G.L., J.A. Strickland, and T.A. Walsh. 1994. Inhibition of Diabrotica spp. larval growth by a multicystatin from potato tubers. J. Insect Physiol. 40:893-900.

Ryan, C.A. 1990. Proteinase inhibitors in plants: Genes for improving defenses against insects and pathogens. Annu. Rev. Phytopathol. 28:425-443.

Solomon, M.B., Belenghi, M. Delledonne, E. Menachem, and A. Levine. 1999. The involvement of cysteine proteinases and proteinase inhibitor genes in the regulation of programmed cell death in plants. The Plant Cell 11:431-444.

Turk, V. and W. Bode. 1991. The cystatins: Protein inhibitors of cysteine proteinases. FEBS Lett. 2:213-219.

Waldron, C., L.M. Wegrich, P.A.O. Merlo, and T.A. Walsh. 1993. Characterization of a genomic sequence coding for potato multicystatin, an eightdomain cysteine proteinase inhibitor. Plant Mol. Biol. 23:801-812

Yonezawa, H., M. Kaneda, and T. Uchikoba. 1998. A cysteine proteinase from young stems of asparagus: Isolation, properties, and substrate specificity. Biosci. Biotechnol. Biochem. 62:28-33. 